\title{
Unresectable Lung Small Cell Carcinoma
}

National Cancer Institute

\section{Source}

National Cancer Institute. Unresectable Lung Small Cell Carcinoma. NCI Thesaurus. Code C160295.

Small cell lung carcinoma that is not amenable to surgical resection. 